Журнал «Герспективитаінноваціїнауки»

(Серія «Гедагогіка», Серія «Гиихологія»), Серія«Медицина»

№5(5) 2021

УДК 373.5.091:821.161.2:004.42

https://doi.org/10.52058/2786-4952-2021-5(5)-134-142

Воронюк Інна Леонідівна старший учитель української мови та літератури Одеської гімназія №1 імені А.П. Бистріної, Олександровський проспект, 11, м. Одеса, 65000, тел.: (098) 262-22-18, e-mail: voronyukinna81@gmail.com, https://orcid.org/ 0000-0003-4968-7598

\title{
ЗМІШАНЕ НАВЧАННЯ В ПРОЦЕСІ ВИВЧЕННЯ УКРАЇНСЬКОЇ МОВИ ТА ЛІТЕРАТУРИ
}

Анотація. Упровадження сучасних інформаційно-комунікаційних технологій, побудова інформаційно-освітнього середовища, використання методів активного навчання, проєктних і дистанційних технологій відкривають нові перспективи для підвищення ефективності навчального процесу та сприяють розв'язанню означеної проблеми.

Технологізація та інформатизація суспільства породжують нові уявлення про освітні результати майбутніх фахівців, яких неможливо досягнути в умовах традиційної освіти.

Водночас недоліки, які проявляються під час застосування цих технологій, особливо дистанційних, знижують продуктивність навчання за рахунок їх штучності. Реальне спілкування, емоційний контакт учасників навчального процесу, використання матеріальних об'єктів і приладів $є$ важливою передумовою практично-технічної підготовки майбутніх вчителів 3 української мови та літератури та формування їх інформаційно-технічних компетентностей.

Крім того, технічні знання та практичні вміння, якими майбутній фахівець має володіти, не завжди можливо отримати в умовах дистанційного навчання.

Значна складність організації онлайн-навчання полягає в застосуванні операцій, пов'язаних із практично-технічною діяльністю під час вивчення української мови та літератури.

Технологізація та інформатизація як поняття з'явились досить недавно, але вже сьогодні породжують нові уявлення про освіту та її результати. Вччителі української мови та літератури не $\epsilon$ виключенням. Останні роки активно впроваджуються сучасні інформаційно-комунікаційні технології, змінюється інформаційно-освітне середовище, з'являються методи активного навчання, проєктні та дистанційні технології. Перед вчителями відкриваються нові перспективи покращення ефективності навчального процесу у закладах загальної середньої освіти.

Ключові слова: навчання, освіта, змішане навчання, інновації, українська мова, заклад загальної середьої освіти, модель змішаного навчання. 
Voroniuk Inna Leonidivna Senior Teacher of Ukrainian Language and Literature Odesa Gymnaium №1 named after A.P.Bystrina, Alexander Avenue, 11, Odessa, 65000, tel.: (098) 262-22-18, e-mail: voronyukinna81@gmail.com, https://orcid.org/ 0000-0003-4968-7598

\title{
BLENDED LEARNING IN UKRAINIAN LANGUAGE AND LITERATURE CLASSES
}

\begin{abstract}
Introduction of modern information and communication technologies, construction of informational and educational environment, use of the active teaching methods, project and distant technologies, open up new perspectives for increasing the effectiveness of the educational process and contribute to the solution of the discussed problem.

Technologization and informatization of society give rise to new ideas about the educational outcomes of future specialists, which cannot be achieved in conditions and terms of traditional education.

In the meantime, the disadvantages that emerge while using these technologies, especially distant ones, reduce the productivity of learning due to their artificiality. Real communication, emotional contact of participants of the educational process, the use of material objects and devices is an important condition for practical and technical training of future teachers of Ukrainian language and literature and the formation of their informational and technical competences.

Besides, the technical knowledge and practical skills that future specialist needs to master are not always possible to acquire in a distance learning environment.

A significant difficulty in the organization of online learning resides in the use of practical and technical activities in the study of Ukrainian language and literature.

Technologization and informatization as concepts have appeared quite recently, but they are already generating new ideas about education and its outcomes. Teachers of Ukrainian language and literature are not an exception. In recent years, modern information and communication technologies have been actively introduced, the information and education environment is changing, active learning methods, project and distance technologies are appearing. Teachers are exposed to new perspectives for improving the effectiveness of the learning process in general secondary education institutions.
\end{abstract}

Keywords: learning, education, blended learning, innovations, Ukrainian language, general secondary education institution, blended learning model.

Постановка проблеми. Технологізація та інформатизація як поняття з'явились досить недавно, але вже сьогодні породжують нові уявлення про освіту та іï результати. Викладачі української мови і літератури не $\epsilon$ виключенням. Останні роки активно впроваджуються сучасні інформаційнокомунікаційні технології, змінюється інформаційно-освітнє середовище, 3'являються методи активного навчання, проєктні та дистанційні технології. 
Перед сучасними учителями відкриваються нові перспективи покращення ефективності навчального процесу у закладах освіти.

В той же час $\epsilon$ певна кількість недоліків, які з'являються під час впровадження даних технологій. Під час дистанційної форми освіти вчителям гостро не вистачає реального спілкування та емоційного контакту. Крім того, від учасників освітнього процесу вимагається володіння технічними та практичними знаннями.

Не дивлячись на це, є варіант подолати вказані недоліки та підвищити ефективність навчального процесу через впровадження змішаної форми навчання. Поєднуються переваги традиційного та дистанційного навчання, що дозволяє правильно розподіляти навчальний час та покращити підготовку сучасних спеціалістів.

На основі аналізу теорії та практики означеної наукової проблеми виявлено низку суперечностей між: традиційними підходами до педагогічної освіти та вимогами сучасного суспільства, зумовленими пошуком інноваційних шляхів професійного розвитку сучасних фахівців; сучасними вимогами щодо формування професійної компетентності фахівців-філологів та реальним рівнем ऑiі сформованості; потребою впровадження технології змішаного навчання української мови $\mathrm{i}$ літератури та теоретичною нерозробленістю цієї проблематики у педагогічній науці. Подолання зазначених суперечностей передбачає: обгрунтування теоретичних засад розвитку готовності фахівців до впровадження технології змішаного навчання; визначення та обгрунтування моделей організації змішаного навчання українскої мови і літератури.

Актуальність полягає у новій формі організації навчального процесу на уроках української мови та літератури, враховуючи індивідуальні потреби кожного учня шляхом поєднання онлайн та офлайн навчання в один ланцюжок.

Аналіз останніх досліджень i публікацій. Аналіз наукових праць засвідчує актуальність питань, пов'язаних з удосконаленням та модернізацією навчального процесу загалом і професійною підготовкою вчителів-філологів зокрема. Серед перспективних напрямів у галузі професійної підготовки учителів української мови i летаратури виокремимо такі: теоретикометодологічні засади професійної підготовки вчителів-філологів у закладах вищої освіти (Д. Баторський, Х. Гулінська, К. Калішевська-Черемська, С. Лацоні, В. Стриковський, Г. Пенковська ін.); використанню моделі змішаного навчання в системі освіти (О. Спіріна, Ю. Триуса, Є. Желнової, М. Нікітіної, Г. Чередніченко, Л. Шапрана, М. Мохової, І. Воротникової, О. Рафальської, Е. Кадирової та ін.), психолого-педагогічні готовності учасників навчального процесу до використання засобів змішаного навчання (Й. Бауер, М. Бурлейн, Н. Карр, П. Хомчинський, Г. Хораб, М. Ледзінський та ін.); компетентнісний підхід у процесі підготовки фахівців (І. Гушлевська,
О. Глазунова,
Л. Карташова,
Л. Макаренко,
Н. Нагорна,
О. Пометун, 
I. Родигіна, Г. Селевко, В. Сергієнко, Л. Сидорчук та ін.).

Мета статті - виявити ососбливості організації змішаного навчання та схарактеризувати моделі організації змішаного навчання в процесі вивчення української мови та літератури.

Виклад основного матеріалу. Однієї з умов впровадження змішаного навчання в закладах освіти $є$ готовність як педагогічних працівників, так i учнів до змішаного навчання. В. Ю. Биков [1] зазначив, що вирішення цієї проблеми, є дуже складною задачею, залишається остаточно не визначеною $\mathrm{i}$ як наслідок не розв'язаною. Психолого-педагогічна проблема $\epsilon$ вагомим бар'єром на шляху до впровадження інформаційно-комунікаційних технологій в процесі навчання української мови і літератури та одночасно важливою передумовою забезпечення якості навчального процесу.

На думку Ю. В. Триуса [4, с. 57], змішане навчання є педагогічним експериментом, який у його «чистому» вигляді неможливо організувати. Це пов'язано 3 тим, що неможливо створити однакові незмінні умови 3 одним i тим же матеріалом і в такому стані повторити експеримент декілька разів. Отже, педагогічні методи, які використовуються в під час різних форм навчання української літератури, повинні забезпечити вибір оптимальної системи способів розв'язку цієї проблеми, педагогічних впливів з урахуванням зміни об'єктів навчання, дозволити аналізувати не тільки хід навчального процесу, його результати, але й умови, в яких він відбуваються.

Дослідник В. М. Кухаренко [3, с. 117-121] вважає, що освітнє середовище закладів освіти $є$ спеціалізованим і цілеспрямованим простором навчального простору, підсистемою єдиного інформаційного простору систем освіти. Засоби й технології цього середовища формуються освітніми закладами й підпорядковані цілям навчання й виховання певного контингенту тих, хто навчається 3 урахуванням наявних обмежень навчального закладу щодо ресурсного забезпечення навчального процесу.

Ми погоджуємось із вітчизняним науковцем М. І. Жалдаком [2, с. 3-9], що використання сучасних інформаційно-комунікаційних технологій, зокрема цифрових ресурсів, може бути доцільним тільки в тому випадку, якщо було враховано основні психологічні принципи, різнобічні вияви сутності учнів, такі як діяльність, свідомість, воля. Недоцільне використання цифрових освітніх ресурсів у навчальному процесі може зашкодити розвитку особистості учнів та іiі здібностей.

Термін «змішане навчання» $є$ дослівним перекладом англійських слів blended learning. Звернімо увагу, що у англійської версії вживається саме слово learning - вчення, тобто, процес отримання знань та умінь, у якому учень $\epsilon$ активно діючим суб'єктом.

Вперше основні принципи змішаного навчання застосовувалися ще у шістдесятих роках XX століття у корпоративній та вищій освіті, але сам термін був вперше використаний у 1999 р., коли американський Інтерактивний Навчальний Центр розпочав випуск програмного забезпечення, призначеного 
для викладання через Інтернет.

На відміну від інших педагогічних технологій, змішане навчання немає конкретного авторства i складалося багато в чому спонтанно, внаслідок численних спроб змінити існуючі методи i принципи навчання. Така спонтанність та багатофакторність розвитку змішаного навчання викликає складності при аналізі даної технології, які починаються зі спроб сформулювати чітке визначення.

Змішане навчання - це освітня технологія, в якій поєднуються та взаємопроникають очне та електронне навчання 3 можливістю вибору часу, місця, темпу та траєкторії навчання».

Таким чином, технологію змішаного навчання можна розглядати як синергетичну технологію, яка дозволяє більш ефективно використовувати переваги як очного, так і електронного навчання, і нівелювати або взаємно компенсувати недоліки кожного 3 них.

Ми розглядаємо готовність до впровадження змішаного навчання як єдність мотиваційних, когнітивних, рефлексивних та технологічних компонентів.

Мотиваційний компонент має вплив на змішане навчання. Учні відрізняються один від одного більше рівнем мотивації, ніж пізнавальними здібностями. Одні учні можуть мати внутрішню та постійну мотивацію, коли інші - зовнішню та ситуативну. Звідси, навчальна діяльність та успіх суттєво залежать від мотивації.

Когнітивний компонент передбачає знання та розуміння процесів, необхідних для здійснення змішаного навчання, зокрема: принципи роботи комп'ютера, мобільних пристроїв та роботи в Інтернеті; можливості освітніх ресурсів Інтернету; основні типи та загальні принципи функціонування телекомунікаційних систем; особливості процесу засвоєння знань у змішаному навчанні; телекомунікаційний етикет.

Не менш важливим компонентом $є$ рефлексивний. Він передбачає здатність організовувати свою навчальну діяльність, розробляти ефективну систему контролю та самостійно планувати освітній процес.

Технологічна складова охоплює здатність використовувати сучасні інформаційні технології, уміння користуватися електронною поштою та різними засобами для обміну інформацією з іншими користувачами, підтримка діалогу 3 іншими користувачами мережі, робота 3 сучасними системами, пошуку в Інтернеті, підготовка інформації до передачі через мережу Інтернет за допомогою різних програм.

Становлення змішаного навчання у просторі закладів освіти тісно пов'язане 3 процесом інформатизації, що включає у собі як оснащення освітньої організації комп'ютерною технікою, так і зміни в освітніх підходах та методах, що використовуються у навчальному процесі, а також у структурі та форматах управління закладом освіти.

Впровадження технології змішаного навчання є одним 3 можливих рішень 
цієї проблеми. Змішане навчання - це не просто використання технологічних засобів навчання, тобто механічне додавання сучасних інтерактивних технологій до традиційних, а якісно новий підхід, що трансформує структуру та зміст навчання, змінюючи традиційні ролі вчителя та учня, а також навчальне середовище.

Ефективно організоване змішане навчання має безліч переваг:

- дає можливість гнучкості для усіх учасників процесу;

- розвиває в учнів активний підхід до навчання, де вчитель більше не $\epsilon$ джерелом інформації, а лише фасилітатором;

- підсилює цифрові навички учнів та спонукає їх бути самостійними здобувачами освіти;

- дає можливість учителям зробити навчання більш індивідуальним

Використання на уроках змішаного навчання також допоможе розв'язати нагальне питання: як наповнити урок і фізичний простір так, щоб урахувати потреби кожного учня.

Виділяють три складові змішаного навчання: інтерактивна, особиста взаємодія вчителя та учня, а також самоосвіта. У навчальному процесі задіяні всі. Технології дарують учням можливість обрати час, темп і шляхи вивчення матеріалу.

Ми виділяємо наступні базові моделі впровадження змішаного навчання у закладах освіти:

«Перевернутий клас» - це найпростіша модель для реалізації, але вона не завжди відповідає високим стандартам змішаного навчання через те, що не всі вчителіі готові проводити заняття в аудиторії у практичному, інтерактивному форматі [5].

Розглянемо методичний аспект підготовки учнів до активної й продуктивної участі в «перевернутому навчанні».

Учитель, керуючи діяльністю учнів, сам визначає мету читацької діяльності, готує відеопояснення, буктрейлери, схеми, електронні мапи, презентації до теми, надає посилання на ресурси, беручи до уваги рекомендації з предмета українська мова та література та враховуючи його специфіку.

Опанування таким навчанням відбувається поступово. Вчитель готує учнів до самоосвіти на основі опорних схем, пам'яток, конспектів як друкованих, так і електронних, які розміщує в гугл-класі або блозі, чи на певній платформі.

Спочатку словесник мотивує учнів, радить матеріал до однієї теми, вивчає реакцію дітей, їхню готовність до продовження роботи за моделлю. Згодом пропонує учням наперед перелік тем у складі розділу, який вивчатиметься, список літератури.

Так вчитель готує учнів до пізнавальної й пошукової діяльності, дає змогу учням поглибити самостійно знання, навчає нести відповідальність за їхнє здобуття й формування власної літературної компетентності.

Під час самостійної підготовки учні роблять нотатки, спілкуються між 
Журнал«Герспективитаінновації наукиљ

(Серія«Гедагогіка», Серія«ГТихологія», Серія «Медицина»

№5(5) 2021

собою, учителем, упорядковують раніше вивчений матеріал або нові знання, контролюють термін виконання, збагачуються духовно.

На уроці учні працюють у групі, обирають практичні завдання за зацікавленістю й складністю, виконують тестові й пошуково-дослідницькі завдання.

Учитель дає інструкції, щоб учні мали змогу усвідомлено засвоїти матеріал із літератури, теоретичні відомості не повторює, а лише поглиблює.

У вільнений час використовують на уроці для дискусії, аналізу художнього твору, гри-симуляції чи захисту проєктів із літератури, поглиблення й закріплення матеріалу.

Учні вдома працюють у навчальному онлайн-середовищі з використанням власних електронних пристроїв з доступом до Інтернету, знайомляться з новим або закріплюють матеріал, що вивчається. На занятті відбувається закріплення вивченого та актуалізація отриманих знань, яка може проходити у форматі семінару, рольової гри, проєктної діяльності та інших інтерактивних форм.

Ця модель дозволяє уникнути фронтальної форми роботи в класі i реалізувати інтерактивні форми роботи на уроці. При роботі 3 новим матеріалом використання LMS (систем управління навчанням), наприклад Moodle або Classroom, дає можливість вчителю відразу ж перевірити розуміння нового матеріалу учнями. Для цього достатньо створити відповідні завдання та завантажити їх у LMS [5].

Ротаційна модель навчання - курс або предмет, при вивченні якого учні можуть змінювати методи навчання за встановленим графіком або на розсуд вчителя. При цьому хоча б одним із методів є навчання в онлайн-режимі [91].

Інші методи можуть включати такі види діяльності, як заняття в невеликих групах або спільні заняття всьогокласу, групові проєкти, індивідуальні заняття та письмові тестові завдання на папері. Учні навчаються переважно в стінах класу, крім виконання домашніх завдань.

Станцій може бути і дві - станція роботи з вчителем і станція онлайнроботи. У цьому випадку рекомендується проводити заняття проєктної роботи або заняття в інтерактивній формі.

Можливий варіант 3 чотирма станціями - станція роботи 3 вчителем, станція онлайн-роботи, станція роботи над колективним проєктом, станція індивідуальної самостійної роботи. Кількість електронних пристроїв дорівнює кількості учнів, поділеному на кількість груп.

Ділити на групи можна за різними принципами, наприклад:

- готовність до заняття, що можна визначити за допомогою міні опитування на початку заняття або онлайн-опитування, виконаного вдома;

- успішність виконання домашнього завдання чи контрольної роботи;

- наявність прогалин у засвоєнні попередніх тем;

- наявність інтересу до теми заняття (потрібне проведення опитування).

Мета станції роботи з вчителем - надати кожному учневі ефективний 
зворотний зв'язок. Максимальний вплив на якість навчання надає зворотний зв'язок з боку вчителя, тому підвищення якості зворотного зв'язку та збільшення часу контакту вчителя зі студентом позитивно відбиваються на успішності. На станції роботи 3 вчителем у нього з'являється можливість врахувати особливості групи учнів, 3 якими він працює, а також їх індивідуальні особливості за рахунок поділу на групи та зменшення числа учнів у групі.

Наприклад, якщо ви працюєте 3 групою «відстаючих» учнів, можна приділити більше уваги темі, яку вони не зрозуміли, дати кожному учневі зворотній зв'язок з цієї теми та запропонувати індивідуальний план роботи над матеріалом, що викликає труднощі.

Мета станції онлайн-роботи - дати кожному учневі можливість розвинути навички самостійної роботи, особисту відповідальність, розвинути саморегуляцію і навчитися вчитися. На станції онлайн-роботи вони можуть ознайомитися 3 новим матеріалом, перевірити свої знання та потренувати навички. Кількість ресурсів у системі має бути надмірною i досить різноманітною, щоб забезпечити учням можливість досить глибоко познайомитись із темою. Учень отримує доступ до матеріалів не лише одного заняття, але цілої теми для того, щоб дати можливість кожному йти у своєму темпі.

Перевагою змішаного навчання $є$ те, що учень здобуває знання тоді, коли йому зручно, а не лише за умови особистої присутності на уроці. Це може бути і відео, і аудіолекція, завантажені на смартфон чи планшет. Учень опановує матеріал у зручному для себе темпі. Формат індивідуальних консультацій викладача допомагає учням позбутися страху не зрозуміти новий матеріал. Це також допомагає вчителеві спостерігати прогрес і рівень розуміння вивченого кожним окремим учнем.

На уроках не витрачається час на виклад нового матеріалу, завдяки чому для застосування знань створюється більше можливостей. Методика не вимагає спеціальних дорогих технічних пристроїв. Учні матимуть змогу використовувати більшу кількість додаткових джерел під час самостійної підготовки вдома.

Висновки. Змішане навчання обгрунтовуємо як інноваційну форму організації навчального процесу під час вивчення української мови та літератури, зорієнтоване на вирішення різних завдань, що забезпечує успішне виконання функцій цілепокладання, планування, організування, координування, стимулювання, контролювання, оцінювання, аналізу та прогнозування в навчальному процесі.

Розвиток змішаної форми навчання характеризуємо як складний процес позитивних професійних змін закладів освіти та педагогічних працівників, що відбуваються в системі сучасної освіти та набувають реалізації у практичній діяльності.

Впровадження змішаного навчання визначаємо як інтеграційний 
конструкт інформаційної й управлінської діяльності (управління процесом пошуку, опрацювання, створення, передання, засвоєння освітньої інформації (змісту освіти), спрямованої на задоволення потреб, інтересів, мотивів, установок, ціннісних орієнтирів учасників освітнього процесу (на основі їхніх запитів і можливостей) та забезпечення якості освітніх результатів.

3'ясовано, що особливості впровадженння змішаної форми навчання у сфері освіти зумовлені інформаційною основою функціонування освіти як соціального інституту; інформаційними інструментами моделювання педагогічної дійсності й удосконалення освітніх процесів; інформацією як результатом управлінської діяльності; забезпеченням якості освітнього процесу; активним використанням інформаційно-комунікаційних технологій.

\section{Лimepamypa:}

1. Биков В. Ю. Проектний підхід і дистанційне навчання у професійній підготовці управлінських кадрів. [Електронний ресурс] Режим доступу: http://lib.iitta.gov.ua/498/1/Bykov12001.pdf.

2. Жалдак М. І. Комп’ютерно-орієнтовані системи навчання - становлення і розвиток. Науковий часопис НПУ імені М. П. Драгоманова. Серія 2 : Комп'ютерно-орієнтовані системи навчання. 2010. № 9. С. 3-9.

3. Кухаренко В. М. Розвиток дистанційного навчання на сучасному етапі. Науковий вісник Національної академії статистики, обліку та аудиту. 2012. № 2. С. 117-121.

4. Триус Ю. В. Комп'ютерно-орієнтовані методичні системи навчання математичних дисциплін у вищих навчальних закладах : дис... д-ра пед. наук: 13.00.02. Черкаси, 2005. 649 с.

5. LMS: Blackboard, Desire2Learn, Instructure, Moodle и Sakai. Carl Straumsheim, «The Post-LMS LMS», Inside Higher Ed. [Електронний ресурс] Режим доступу: https://www.insidehighered.com/news/2014/07/18/analysts-see-changes-ahead-lms-market-aftersummer-light-news.

\section{References:}

1. Bikov, V. Ju. (2001). Proektnij pidhid $i$ distancijne navchannja $u$ profesijnij pidgotovci upravlins\&apos;kih kadriv. [Project approach and distance learning in the training of managerial staff] Retrived from http://lib.iitta.gov.ua/498/1/Bykov1-2001.pdf [in Ukrainian].

2. Zhaldak, M. I. (2010). Komp'juterno-orientovani sistemi navchannja - stanovlennja i rozvitok [Computer-based learning systems - formation and development]. Naukovij chasopis NPU imeni M. P. Dragomanova. Serija 2 : Komp\&apos;juterno-orientovani sistemi navchannja Scientific journal of NPU named after MP Drahomanov. Series 2: Computer-based learning systems, 9, 3-9 [in Ukrainian].

3. Kuharenko, V. M. (2012). Rozvitok distancijnogo navchannja na suchasnomu etapi [Development of distance learning at the present stage]. Naukovij visnik Nacional\&apos;noï akademiï statistiki, obliku ta auditu - Scientific Bulletin of the National Academy of Statistics, Accounting and Auditing, 2, 117-121 [in Ukrainian].

4. Trius, Ju. V. (2005). Komp\&apos;juterno-orientovani metodichni sistemi navchannja matematichnih disciplin $\mathrm{u}$ vishhih navchal\&apos;nih zakladah [Computer-oriented methodical systems of teaching mathematical disciplines in higher educational institutions]. Doctor's thesis. Cherkasi [in Ukrainian].

5. LMS: Blackboard, Desire2Learn, Instructure, Moodle и Sakai. Carl Straumsheim, «The Post-LMS LMS», Inside Higher Ed. Retrived from https://www.insidehighered.com/ news/2014/07/18/analysts-see-changes-ahead-lms-market-after-summer-light-news [in Englush]. 